\title{
IMPLEMENTASI PUTUSAN MAHKAMAH KONSTITUSI NOMOR 46/PUU-VIII/2010 TENTANG ANAK DI LUAR KAWIN
}

Kajian Putusan Nomor 329 K/AG/2014

\section{THE IMPLEMENTATION OF CONSTITUTIONAL COURT DECISION NUMBER 46/PUU-VIII/2010 ON EXTRAMARITAL CHILD}

An Analysis of Court Decision Number 329 K/AG/2014

\author{
Nurhadi \\ Mahkamah Syar'iyah Sabang \\ Jl. Yos Sudarso No. 101 Kota Sabang 23522 \\ E-mail: nurhadi1980@gmail.com
}

Naskah diterima: 14 Februari 2017; revisi: 5 Oktober 2017; disetujui 6 Agustus 2018

http://dx.doi.org/10.29123/jy.v11i2.66

\begin{abstract}
ABSTRAK
Putusan Nomor 329 K/AG/2014 terkait kedudukan anak di luar kawin yang berinisial MIR. MIR tidak diakui oleh ayahnya. Ibunya yang berinisial AM mengajukan gugatan isbat nikah (pengesahan perkawinannya) yang dikumulasikan dengan pengesahan kedudukan anaknya berdasarkan pada Putusan Mahkamah Konstitusi Nomor 46/PUU-VIII/2010. Putusan tersebut menolak seluruh gugatan AM dengan pertimbangan pengadilan agama tidak berwenang mengesahkan perkawinan yang terjadi setelah berlakunya Undang-Undang Nomor 1 Tahun 1974, dan permohonan pengesahan kedudukan anak di luar kawin bukan kewenangan pengadilan agama. Dari beberapa permasalahan yang ditemui, penelitian ini mengulas tiga rumusan masalah. Pertama, apakah dalam Putusan Nomor 329 K/AG/2014 sudah tercermin aspek yuridis, aspek sosiologis, dan aspek filosofis? Kedua, apakah pertimbangan hukum dalam Putusan Nomor 329 K/AG/2014 telah mengimplementasikan Putusan Mahkamah Konstitusi Nomor 46/PUUVIII/2010? Ketiga, bagaimana kondisi petitum tentang anak di luar kawin apabila ditinjau menurut teori keadilan, teori perlindungan, teori kewenangan, teori
\end{abstract}

hukum progresif, dan teori mashlahah? Metode yang digunakan dalam penelitian ini adalah deskriptif analitis. Hasil penelitian menunjukkan bahwa dalam putusan tersebut lebih mengutamakan aspek yuridis, sedangkan aspek sosiologis dan filosofis cenderung diabaikan. Putusan tersebut tidak mengimplementasikan Putusan Mahkamah Konstitusi Nomor 46/PUU-VIII/2010. Berdasarkan teori keadilan, teori perlindungan hukum, teori kewenangan, teori hukum progresif, dan teori mashlahah, petitum tentang anak di luar kawin dapat dikabulkan.

Kata kunci: anak di luar kawin, anak biologis, Putusan Mahkamah Konstitusi, Putusan Mahkamah Agung.

\section{ABSTRACT}

The Supreme Court Decision Number 329 K/AG/2014 concerns on the case of an out-of-wedlock status with the initials MIR who was disowned by her father. The mother of the child initials AM, filed a lawsuit related to itsbat marriage (marriage ratification) which was accumulated with the ratification of her child's status based on the Constitutional Court Decision Number 46/ 
PUU-VIII/2010. The decision completely rejected the lawsuit considering that the Religious Court was not authorized to ratify a marriage that occurred after the enactment of Law Number 1 of 1974, and the request to legalize the status of an extramarital child was not the authority of the religious court. Of the several problems encountered, in this analysis three formulations of the problem were discussed. First, has the Decision Number $329 \mathrm{~K} / \mathrm{AG} / 2014$ reflected the juridical, sociological, and philosophical aspects? Second, have these legal considerations of Decision Number 329 K/AG/2014 implemented the Constitutional Court Decision Number 46/PUU-VIII/2010? Third, how is the condition of

\section{PENDAHULUAN}

\section{A. Latar Belakang}

Di Indonesia, kedudukan anak dalam hukum keluarga dapat dikategorikan menjadi dua macam, yaitu anak yang sah dan anak yang tidak sah (Satrio, 2005: 5). Definisi mengenai anak sah diatur dalam Pasal 42 Undang-Undang Nomor 1 Tahun 1974 tentang Perkawinan yang berbunyi: "Anak yang sah adalah anak yang dilahirkan dalam atau sebagai akibat perkawinan yang sah." Pasal tersebut dijabarkan lebih lanjut dalam

Pasal 99 Kompilasi Hukum Islam yang berbunyi: “Anak yang sah adalah: (a) anak yang dilahirkan dalam atau akibat perkawinan yang sah; (b) hasil perbuatan suami istri yang sah di luar rahim dan dilahirkan oleh istri tersebut."

Definisi mengenai anak tidak sah telah diatur dalam Pasal 43 ayat (1) Undang-Undang Nomor 1 Tahun 1974 yang berbunyi: “Anak yang dilahirkan di luar perkawinan hanya mempunyai hubungan perdata dengan ibunya dan keluarga ibunya." Pasal tersebut dijabarkan lebih lanjut dalam Pasal 100 Kompilasi Hukum Islam yang berbunyi: "Anak yang lahir di luar perkawinan petitum related to extramarital children viewed from the theory of justice, protection theory, authority theory, progressive legal theory, and mashlahah theory? The method used in this research is descriptive-analysis. The results showed that the decision prioritize the juridical aspect. Meanwhile, the sociological and philosophical aspects tend to be neglected. The decision does not seem to implement the Constitutional Court Decision Number 46/PUU-VIII/2010. Based on the theory of justice, legal protection, authority, progressive law and mashlahah, petitum regarding extramarital children can be granted.

Keywords: extramarital children, biological child, Constitutional Court Decision, Supreme Court Decision.

hanya mempunyai hubungan nasab dengan ibunya dan keluarga ibunya" (Rofiq, 2013: 178).

Anak merupakan hasil dari adanya hubungan biologis antara laki-laki dan perempuan, sehingga kedudukan anak sangat tergantung pada keabsahan perkawinan orang tuanya. Di Indonesia, sedikitnya terdapat dua model perkawinan yang diakui oleh masyarakat, yaitu perkawinan yang tercatat dan perkawinan tidak tercatat. Perkawinan yang tidak tercatat, di masyarakat biasanya disebut dengan nikah siri, nikah di bawah tangan atau nikah liar (Anshary MK, 2010: 13). Meskipun mayoritas ulama (tokoh agama) di Indonesia mengakui tentang keabsahan perkawinan tersebut, namun menurut hukum yang berlaku di Indonesia perkawinan tersebut tidak sah, sehingga status anak dari perkawinan siri tersebut disebut anak di luar nikah/kawin, yang tidak dapat dinasabkan kepada ayahnya.

Keadaan seperti ini dialami oleh MIR, anak dari AM, hasil perkawinannya dengan M. Permasalahan berawal dari perkawinan $\mathrm{M}$ dengan AM pada tanggal 20 Desember 1993. Pernikahan tersebut tidak tercatat di Kantor Urusan Agama, kemudian pada tahun 1998 keduanya 
bercerai. Setelah bercerai, M tidak memenuhi kewajibannya sebagai ayah, bahkan M tidak mengakui MIR sebagai anak kandungnya. Sikap $\mathrm{M}$ yang demikian itu membuat AM berusaha secara kekeluargaan melalui Komisi Perlindungan Anak Indonesia melakukan mediasi, namun tidak membuahkan hasil.

AM mengajukan permohonan isbat nikah (pengesahan nikah) ke Pengadilan Agama Tigaraksa, yang kemudian pada intinya menolak permohonan pemohon. Bulan Juli 2010, AM berjuang lewat Mahkamah Konstitusi dengan mengajukan gugatan uji materiil (judicial review) untuk mendapatkan pengakuan tentang status hukum anaknya (MIR) sebagai anak yang sah dari AM dan M. Hasil uji materiil tersebut, hanya diterima sebagian oleh Mahkamah Konstitusi.

Hal ini dapat dilihat dalam amar Putusan Nomor 46/PUU-VIII/2010, yang menyatakan bahwa Pasal 43 ayat (1) Undang-Undang Nomor 1 Tahun 1974, harus dibaca “Anak yang dilahirkan di luar perkawinan mempunyai hubungan perdata dengan ibunya dan keluarga ibunya serta dengan laki-laki sebagai ayahnya yang dapat dibuktikan berdasarkan ilmu pengetahuan dan teknologi dan/ atau alat bukti lain menurut hukum mempunyai hubungan darah, termasuk hubungan perdata dengan keluarga ayahnya."

Berbekal putusan tersebut, AM mengajukan gugatan pengesahan anak biologis yang terdaftar di Kepaniteraan Pengadilan Agama Jakarta Selatan dengan Nomor 1241/PDT.G/2012/PA.JS. Pengadilan Agama Jakarta Selatan membacakan putusan atas gugatan tersebut, yang pada intinya mengabulkan sebagian gugatan penggugat (AM), dengan menyatakan anak yang bernama MIR, lahir pada tanggal 5 Februari 1996 adalah anak di luar perkawinan dari penggugat (AM) dan M. AM tidak terima atas putusan tersebut. AM mengajukan banding ke Pengadilan Tinggi Agama Jakarta yang mengetok palu dengan memberikan pertimbangan tambahan, yang pada intinya menguatkan pertimbangan putusan Pengadilan Agama Jakarta Selatan. AM tidak terima lagi atas putusan Pengadilan Tinggi Agama Jakarta tersebut, kemudian mengajukan kasasi ke Mahkamah Agung. Melalui Putusan Nomor 329 K/AG/2014, Mahkamah Agung menolak seluruh gugatan penggugat.

\section{B. Rumusan Masalah}

Berdasarkan latar belakang dan kronologis kasus di atas, maka masalah yang perlu dijawab dalam kajian ini adalah:

1. Apakah pertimbangan dalam Putusan Nomor 329 K/AG/2014 sudah tercermin aspek yuridis (kepastian hukum), aspek sosiologis (kemanfaatan), dan aspek filosofis (keadilan)?

2. Apakah pertimbangan hukum dalam Putusan Nomor 329 K/AG/2014 telah mengimplementasikan Putusan Nomor 46/ PUU-VIII/2010?

3. Bagaimana kondisi petitum tentang anak di luar kawin apabila ditinjau menurut teori keadilan, teori perlindungan, teori kewenangan, teori hukum progresif, dan teori mashlahah?

\section{Tujuan dan Kegunaan}

Tujuan kajian ini adalah untuk mengetahui apakah aspek yuridis (kepastian hukum), aspek sosiologis (kemanfaatan), dan aspek filosofis (keadilan) sudah tercermin dalam Putusan Nomor 329 K/AG/2014. Selain itu untuk 
mengetahui apakah putusan tersebut telah mengimplementasikan Putusan Nomor 46/ PUU-VIII/2010, dan bagaimana kondisi petitum tentang anak di luar kawin apabila ditinjau menurut teori keadilan, teori perlindungan, teori kewenangan, teori hukum progresif, dan teori mashlahah.

Kegunaan penelitian ini diharapkan berguna bagi pengembangan ilmu hukum, memperluas dan menambah wawasan, menambah khazanah pemikiran hukum pada umumnya dan hukum keluarga pada khususnya, dan memberikan kontribusi dalam upaya mewujudkan keadilan dalam rangka penyelesaian perkara gugatan/ permohonan anak di luar nikah, serta untuk mengantisipasi prolematika hukum yang terus berkembang.

\section{Tinjauan Pustaka}

Kajian Putusan Nomor 329 K/AG/2014 pernah ditulis dengan judul "Hak Anak Sebagai Ahli Waris dalam Perkawinan Siri (Kajian Putusan Nomor 329 K/AG/2014)," yang isi kesimpulannya adalah sebagai berikut:

"Putusan Kasasi Mahkamah Agung memperkuat putusan pengadilan sebelumnya untuk tidak memberlakukan Putusan Mahkamah Konstitusi kepada kasus MIR dan AM karena prinsip non retroactive. Selain itu, putusan juga menolak untuk menetapkan pengesahan perkawinan siri AM dan M. Alasannya adalah perkawinan siri mereka dilangsungkan pada 20 Desember 1993 atau setelah berlakunya Undang-Undang Perkawinan 1974. Meskipun berhukum sah menurut hukum Islam namun tidak dicatatkan pada kantor urusan agama, pengadilan tetap tidak bisa melakukan pengesahan perkawinan (isbat nikah) sesuai huruf a angka 22 Penjelasan Pasal 49 ayat (2) Undang-Undang Peradilan Agama 2006. Sebagai konsekuensi hukumnya, majelis hakim menolak untuk memberikan hubungan keperdataan antara MIR sebagai anak luar kawin dengan $\mathrm{M}$ sebagai bapak biologisnya. Dengan demikian, MIR tidak bisa mendapatkan warisan dari almarhum M" (Tobroni, 2015: 100).

Tulisan ini akan mengkaji Putusan Nomor 329 K/AG/2014 dengan menggunakan teori lain, yakni teori keadilan, teori perlindungan hukum, teori kewenangan, teori hukum progresif, dan teori mashlahah.

\section{Teori Keadilan}

Aquinas dalam Sujana(2015), membedakan keadilan atas dua kelompok, yaitu keadilan umum (justitia generalis) dan keadilan khusus (justitia spesialis). Keadilan umum adalah keadilan menurut kehendak undang-undang, yang harus ditunaikan demi kepentingan umum. Keadilan khusus adalah keadilan atas dasar kesamaan atau proporsionalitas. Keadilan khusus ini dibedakan menjadi: a) keadilan distributif (iustitia distributive); b) keadilan komutatif (iustitia commutativa); dan c) keadilan vindikatif (iustitia vindicativa) (Sujana, 2015: 19).

Keadilan distributif adalah keadilan yang secara proporsional diterapkan dalam lapangan hukum publik secara umum. Sebagai contoh, negara hanya akan mengangkat seseorang menjadi hakim, apabila orang itu memiliki kecakapan menjadi hakim. Keadilan komutatif adalah keadilan dengan mempersamakan antara prestasi dan kontraprestasi. Keadilan vindikatif adalah keadilan dalam tindak pidana.

Seorang dianggap adil apabila ia dipidana badan atau sesuai dengan besarnya hukuman yang telah ditentukan atas tindakan pidana yang dilakukannya (Sumaryono, 1995: 124). 


\section{Teori Perlindungan Hukum}

Hadjon mengatakan ada dua macam perlindungan hukum bagi rakyat, yaitu perlindungan hukum yang preventif dan perlindungan hukum yang represif. Segala sarana, di antaranya peraturan perundang-undangan, yang memfasilitasipengajuankeberatan-keberatanoleh rakyat sebelum keputusan pemerintah mendapat bentuk definitif, merupakan perlindungan yang preventif. Penanganan perlindungan hukum bagi rakyat oleh pengadilan merupakan perlindungan hukum yang represif (Hadjon, 2007: 2).

\section{Teori Kewenangan atau Kompetensi}

Kewenangan yang dimiliki oleh pengadilan termasuk kewenangan atribusi. Dalam praktik hukum acara perdata, kompetensi ada dua macam, yaitu kompetensi absolut (kewenangan absolut) dan kompetensi relatif (kewenangan relatif) (Sutantio \& Oeripkartawinata, 2002: 11).

Kompetensi relatif diartikan sebagai kekuasaan peradilan yang satu jenis dan satu tingkatan, dalam perbedaannya dengan kekuasaan pengadilan yang sama jenis dan sama tingkatan lainnya. Atau dengan kata lain bahwa setiap lembaga peradilan mempunyai wilayah hukum tertentu, dalam hal ini meliputi satu kota atau satu kabupaten. Sedangkan kompetensi absolut adalah kewenangan suatu badan peradilan untuk memeriksa perkara tertentu yang secara mutlak tidak dapat diperiksa oleh badan peradilan lain. Ini artinya kekuasaan peradilan yang berhubungan dengan pembagian kekuasaan kehakiman antara lingkungan badan-badan peradilan, yakni apakah suatu perkara itu menjadi kewenangan lingkungan peradilan umum, peradilan agama, peradilan militer atau peradilan tata usaha negara (Harahap, 2013: 180).

\section{Teori Hukum Progresif}

Rahardjo menganggap sebagai tipe hukum yang ideal, sebagai tipe hukum yang memperjuangkan keadilan prosedural dan keadilan substantif adalah hukum progresif. Adapun pengertian hukum progresif itu sendiri adalah mengubah secara cepat, melakukan pembalikan yang mendasar dalam teori dan praktik hukum, serta melakukan berbagai terobosan. Pembebasan tersebut didasarkan pada prinsip bahwa hukum adalah untuk manusia dan bukan sebaliknya, dan hukum itu tidak ada untuk dirinya sendiri, melainkan untuk sesuatu yang lebih luas, yaitu untuk harga diri manusia, kebahagiaan, kesejahteraan, dan kemuliaan manusia (Rahardjo, 2007: 154).

\section{Teori Mashlahah}

Dalam bahasa Arab, mashlahah (jamaknya mashalih) merupakan sinonim dari kata manfaat dan lawan dari kata mafsadat (kerusakan). Sedangkan mashlahah secara epistemologi, di antaranya menurut Al-Khawarizmi dalam Manan (2007) adalah memelihara tujuan hukum Islam dengan menolak bencana atau kerusakan yang merugikan diri makhluk manusia. Sebagaimana diketahui tujuan hukum Islam adalah untuk memelihara agama, akhlak, jiwa, dan keturunan (Manan, 2007: 262). Tidak jauh berbeda dengan pendapat Al-Khawarizmi di atas, Al-Ghazali dalam Manan (2007) merumuskan mashlahah sebagai suatu tindakan memelihara tujuan syara' atau tujuan hukum Islam. Sedangkan tujuan hukum Islam menurut Al-Ghazali adalah memelihara lima hal di atas. Setiap hukum yang mengandung tujuan memelihara salah satu dari lima hal di atas disebut mashlahah, dan setiap hal yang meniadakannya disebut mafsadah, dan 
menolak mafsadah disebut mashlahah (Manan, 2007: 262).

\section{METODE}

Penelitian ini adalah bersifat deskriptif analitis. Jenis penelitian ini adalah penelitian hukum normatif, yaitu penelitian dilakukan dengan cara menganalisis hukum yang tertulis dari bahan pustaka atau data sekunder belaka, yang lebih dikenal dengan nama bahan hukum sekunder dan bahan acuan dalam bidang hukum atau bahan rujukan bidang hukum. Data yang dikumpulkan melalui studi dokumen terhadap bahan kepustakaan antara lain meliputi bahan hukum primer seperti peraturan perundangundangan dan putusan pengadilan.

Bahan hukum sekunder yaitu bahanbahan yang bersumber dari pendapat ilmiah para sarjana dan buku-buku literatur yang ada kaitannya dengan fokus dengan penelitian ini. Bahan hukum tersier seperti kamus hukum, ensiklopedia, majalah, surat kabar, internet, dan jurnal-jurnal. Untuk analisis data, penulis menggunakan metode analisis kualitatif.

\section{HASIL DAN PEMBAHASAN}

\section{A. Keabsahan Perkawinan di Indonesia}

Pasal 1 Undang-Undang Nomor 1 Tahun 1974 menyebutkan, bahwa perkawinan adalah ikatan lahir batin antara seorang pria dengan seorang wanita sebagai suami istri dengan tujuan membentuk keluarga (berumah tangga) yang bahagia dan kekal berdasarkan Ketuhanan Yang Maha Esa.

Perkawinanbukanhanya sekedarmemenuhi kebutuhan biologis dan kehendak kemanusiaan, yaitu suatu ikatan atau hubungan lahir batin antara seorang pria dan seorang wanita. Dengan tujuan sebagai suatu usaha untuk mewujudkan kehidupan yang bahagia yang berlandaskan Ketuhanan Yang Maha Esa, sehingga perkawinan yang akan dilakukan mempunyai kekuatan atau hubungan yang sangat erat dengan agama dan kerohanian. Hal ini disebabkan karena suatu perkawinan bukan hanya hubungan jasmaniahnya saja, tetapi hubungan batiniah (agama dan kerohanian) mempunyai peran yang sangat penting dalam perkawinan (Rasyidi, 1991: 5).

Disebutkan dalam Kompilasi Hukum Islam, pengertian perkawinan dan tujuannya dinyatakan dalam Pasal 2 dan 3. Pasal 2 menyatakan, perkawinan menurut hukum Islam adalah pernikahan, yaitu akad yang sangat kuat atau mitsaqan ghaliza untuk mentaati perintah Allah dan melaksanakannya merupakan ibadah. Pasal 3 menyebutkan bahwa perkawinan bertujuan untuk mewujudkan kehidupan rumah tangga yang sakinah, mawaddah, dan rahmah.

Menurut Undang-Undang Nomor 1 Tahun 1974, mengenai keabsahan suatu perkawinan terdapat dalam Pasal 2, yaitu perkawinan yang dilakukan menurut hukum masing-masing agamanya dan kepercayaannya (ayat (1)), serta dicatatkan di instansi pemerintah yang menangani bidang tersebut (ayat (2)).

Masalah sah atau tidaknya suatu perkawinan ditentukan oleh agamanya masingmasing. Bagi yang beragama Islam harus terpenuhi syarat dan rukun suatu perkawinannya. Sehingga apabila syarat dan rukun nikah sudah terpenuhi, maka perkawinan tersebut sudah sah secara agama. Namun perkawinan tersebut belum dianggap sah oleh negara apabila tidak dicatatkan di Kantor Urusan Agama, sehingga perkawinan tersebut harus dicatatkan dahulu, 
karena pencatatan tersebut berfungsi sebagai pengakuan, perlindungan, dan kepastian hukum. Perkawinan yang sah secara agama namun tidak dicatatkan biasanya disebut dengan nikah siri, nikah di bawah tangan atau nikah liar (Anshary MK, 2010: 13 \& 26).

Nikah siri artinya nikah secara rahasia, lazim juga disebut dengan nikah di bawah tangan atau nikah liar. Nikah siri dapat dibedakan menjadi dua jenis. Pertama, akad nikah yang dilakukan oleh seorang laki-laki dengan seorang perempuan tanpa hadirnya orang tua/wali si perempuan, biasanya wali nikahnya seorang ulama tanpa pendelegasian dari wali nikah yang berhak. Kedua, akad nikah yang dilakukan yang telah memenuhi syarat dan rukun suatu perkawinan sesuai hukum Islam, namun tidak dicatatkan menurut Undang-Undang Perkawinan.

Istilah perkawinan di bawah tangan muncul setelah diberlakukannya secara efektif Undang-Undang Perkawinan pada tahun 1974. Perkawinan di bawah tangan yang disebut juga sebagai perkawinan liar karena perkawinannya dilaksanakan di luar pengawasan pemerintah atau perkawinan yang dilakukan di luar ketentuan hukum perkawinan yang berlaku secara positif di Indonesia. Meskipun demikian, tidak semua perkawinan yang dilakukan secara siri/di bawah tangan merupakan perkawinan yang tidak sah (Anshary MK, 2010: 27).

Sahnya perkawinan adalah terpenuhinya syarat dan rukun yang ditentukan oleh agama sebagaimana ketentuan Pasal 2 ayat (1) UndangUndang Perkawinan. Namun demikian, Pasal 2 ayat (1) tidak dapat dipisahkan dari ketentuan Pasal 2 ayat (2), yaitu kewajiban administratif untuk mencatatkan perkawinan. Kewajiban administratif tersebut berfungsi untuk melindungi dan memenuhi hak asasi yang bersangkutan dan melindungi dari akibat hukum yang sangat luas. Misalnya hak-hak wanita sebagai istri, hak-hak anak yang kelak dilahirkan dalam perkawinan tersebut. Sehingga dengan dicatatkannya suatu perkawinan, hak-hak yang timbul dari suatu perkawinan tersebut dapat dilindungi oleh negara. Oleh karena pentingnya fungsi pencatatan tersebut, maka Pasal 6 Kompilasi Hukum Islam menyatakan bahwa perkawinan yang dilakukan di luar pengawasan pegawai pencatat nikah tidak mempunyai kekuatan hukum.

\section{B. Kedudukan Hukum Anak Menurut Hukum Indonesia}

Anakmerupakanhasil dariadanyahubungan biologis antara laki-laki dan perempuan. Apabila anak tersebut lahir dari perkawinan yang sah menurut hukum Islam, maka anak tersebut juga menjadi anak sah. Demikian juga sebaliknya apabila anak tersebut lahir dari perkawinan yang tidak sah, maka anak tersebut juga berkedudukan sebagi anak tidak sah, sehingga hanya mempunyai hubungan perdata dengan ibunya.

Dalam pandangan hukum Islam, anak hasil hubungan di luar nikah disebut dengan istilah anak zina (walad al-zina), anak syubhat atau anak li'an, dan dianggap sebagai anak yang tidak sah (Manan, 2014: 83). Sebagaimana tertera dalam beberapa sabda Nabi Muhammad SAW, yang pada intinya menerangkan bahwa anak hasil zina dinasabkan kepada pemilik kasur/ suami dari perempuan yang melahirkan (firasy) atau dinasabkan kepada ibunya saja.

DiIndonesia, perkawinanyang diakuiadalah perkawinan yang dilakukan menurut hukum masing-masing agama dan kepercayaannya, dan dicatatkan di instansi pemerintah yang menangani 
bidang tersebut sebagaimana ketentuan Pasal 2 Undang-Undang Perkawinan.

Akibat perkawinan yang tidak tercatat, perkawinan tersebut tidak mendapat pengakuan, perlindungan, dan kepastian hukum dari negara. Sehingga anak yang lahir dari perkawinan tersebut berkedudukan sebagai anak yang tidak sah, dan hanya mempunyai hubungan perdata dengan ibunya saja (Pasal 43). Namun apabila dapat dibuktikan di depan pengadilan bahwa anak tersebut adalah anak biologis dari ayah yang menghamili ibunya (vide Putusan Nomor 46/PUU-VIII/2010), maka anak tersebut berkedudukan sebagai anak biologis dari lakilaki tersebut dan mempunyai hubungan perdata dengan ayah biologisnya tersebut.

\section{Analisis Putusan Nomor 329 K/AG/2014}

Mahkamah Agung dalam putusan kasasi tersebut memberikan pertimbangan sebagai berikut:

Bahwa judex facti Pengadilan Tinggi Agama Jakarta yang menguatkan Putusan Pengadilan Agama Jakarta Selatan keliru dalam mempertimbangkan dan memutus perkara in casu, dengan pertimbangan sebagai berikut:

1. Bahwa kewenangan mengadili pengadilan agama di bidang perkawinan sebagaimana dijelaskan di dalam penjelasan Pasal 49 ayat (2) Undang-Undang Nomor 7 Tahun 1989 tentang Peradilan Agama, yang telah diubah dengan Undang-Undang Nomor 3 Tahun 2006 dan perubahan kedua dengan Undang-Undang Nomor 50 Tahun 2009 ada 22 poin yang dimaksud dengan bidang perkawinan.

2. Bahwa pemohon kasasi di dalam petitum angka 2 mengajukan tuntutan agar pengadilan menyatakan bahwa perkawinan antara penggugat (AM) dan alm. Drs. M yang dilangsungkan pada tanggal 20 Desember 1993 adalah perkawinan yang sah menurut hukum Islam, namun perkawinan tersebut tidak dapat dicatatkan. Tuntutan tersebut tidak termasuk kewenangan pengadilan agama karena angka 22 Penjelasan Pasal 49 ayat (2) hanya memberi kewenangan untuk menyatakan sahnya perkawinan yang terjadi sebelum UndangUndang Nomor 1 Tahun 1974 tentang Perkawinan dan dijalankan menurut peraturan yang lain.

3. Bahwa dengan demikian putusan judex facti Pengadilan Tinggi Agama Jakarta yang menguatkan Putusan Pengadilan Agama Jakarta Selatan dalam hal menolak gugatan tentang pengesahan perkawinan ini casu sudah tepat dan benar.

4. Bahwa pemohon kasasi di dalam petitum angka 3 mengajukan tuntutan agar pengadilan menyatakan sebagai hukum bahwa anak laki-laki yang bernama MIR yang lahir di Jakarta, pada hari Senin, tanggal 5 Februari 1996 adalah anak yang dilahirkan dari perkawinan yang sah menurut hukum Islam, sedangkan petitum angka 4 menuntut untuk dinyatakan sebagai anak di luar perkawinan yang mempunyai hubungan perdata dengan alm. Drs. M sebagai ayahnya. Antara petitum angka 3 dengan petitum angka 4 tersebut terjadi kontradiksi, di satu sisi agar dinyatakan sebagai anak sah, dan di sisi lain agar dinyatakan sebagai anak di luar nikah.

5. Bahwa tuntutan pemohon kasasi tentang sah atau tidaknya seorang anak sebagaimana bunyi penjelasan Pasal 49 ayat (2) Undang-Undang Nomor 7 Tahun 1989 angka 14: "Putusan tentang sah atau tidaknya seorang anak." Dalam hal pengesahan status anak, Pasal 99 Kompilasi Hukum Islam jo. Pasal 42 UndangUndang Nomor 1 Tahun 1974 secara tegas menyatakan: "Anak yang sah adalah anak yang dilahirkan dalam 
atau sebagai akibat perkawinan yang sah."

6. Bahwa dengan ditolaknya tuntutan pemohon kasasi/penggugat mengenai pengesahan perkawinan pada petitum angka 2 di atas, maka tuntutan pemohon kasasi/penggugat agar MIR dinyatakan sebagai anak yang sah, juga harus ditolak.

7. Bahwa tuntutan untuk dinyatakan sebagai anak di luar perkawinan tidak termasuk kewenangan pengadilan agama mengadilinya sebagaimana telah disebutkan di atas, bahwa kewenangan pengadilan agama sesuai Pasal 49 ayat (2) UndangUndang Nomor 7 Tahun 1989 tentang Peradilan Agama, yang telah diubah dengan Undang-Undang Nomor 3 Tahun 2006 dan perubahan kedua dengan Undang-Undang Nomor 50 Tahun 2009 berikut penjelasan Pasal 49 ayat (2) tersebut, kewenangan yang ada dalam perkara in casu untuk menyatakan apakah anak sah atau tidak sah menurut hukum yang berlaku.

Oleh karenanya judex facti (Pengadilan Tinggi Agama Jakarta dan Pengadilan Agama Jakarta Selatan) yang mengabulkan tuntutan penggugat tentang status anak di luar kawin adalah putusan yang telah menyimpang dari tugas dan wewenang hakim pada peradilan agama yang wajib memutus berdasarkan hukum Islam, sebagaimana hasil kesepakatan ulama dan cendekiawan Muslim Indonesia yang telah dituangkan di dalam hukum perkawinan Kompilasi Hukum Islam.

Dalam menganalisis pertimbangan hukum tersebut, penulis menggunakan teori keadilan sebagai teori utama (grand theory) dalam kajian ini, ditambah teori hukum progresif dan teori mashlahah sebagai teori menengah (middle range theory), sedangkan untuk teori terapannya (applied theory) digunakan teori kewenangan dan teori perlindungan hukum, dengan penjabaran sebagai berikut:
1) Untuk menganalisis pertimbangan hukum pada angka 1,2, dan 3, yang pada pokoknya menyatakan bahwa pengadilan agama tidak berwenang mengadili perkara isbat nikah yang dilakukan setelah berlakunya UndangUndang Perkawinan pada tahun 1974, maka petitum angka 2 harus ditolak. Untuk mengalisis pertimbangan tersebut penulis menggunakan teori kewenangan atau teori kompetensi. Petitum ini mengajukan isbat nikah, dan dinyatakan ditolak, karena perkawinan yang bersangkutan terjadi pada tahun 1993 dan Undang-Undang Perkawinan sudah berlaku secara efektif sejak tahun 1974, sehingga pengadilan agama tidak berwenang mengadili perkara tersebut.

Menurut penulis pertimbangan hukum tersebut terasa aneh, karena dalam hukum acara perdata, perkara yang ditolak biasanya karena apa yang digugat tidak terbukti. Sedangkan dalam perkara tersebut telah terbukti adanya perkawinan berdasarkan bukti-bukti yang diajukan penggugat AM. Seharusnya kalau petitum tersebut ingin ditolak, maka pertimbangannya adalah karena tergugat (M) pada saat melangsungkan perkawinan dengan AM tidak ada izin poligami dari pengadilan agama. Sehingga dalam perkawinan yang bersangkutan terdapat halangan hukum sebagaimana ketentuan Pasal 9 jis. Pasal 3 ayat (2) dan Pasal 4 Undang-Undang Perkawinan, Pasal 40 dan Pasal 56 ayat (1) dan (3) Kompilasi Hukum Islam. Jika pertimbangannya seperti itu, maka cukup mengambil alih pertimbangan hukum judex facti (Pengadilan Agama Jakarta Selatan dan Pengadilan Tinggi 
Agama Jakarta), dan pertimbangan ini juga yang dijadikan alasan dalam penolakan isbat nikah ketika di Pengadilan Agama Tigaraksa, yaitu:

"Menimbang, bahwa perkawinan antara AM dan M yang dilangsungkan pada tanggal 20 Desember 1993, berdasarkan pengakuan penggugat dan keterangan saksi-saksi terdapat halangan perkawinan, yaitu tidak memenuhi ketentuan Pasal 3 dan Pasal 4 Undang-Undang Perkawinan, yaitu $M$ tidak mendapat izin poligami dari pengadilan di daerah tempat tinggalnya, memang $\mathrm{M}$ tidak pernah meminta izin poligami dari pengadilan di daerah tempat tinggalnya karena pada saat itu M sebagai pejabat negara. Oleh karena itu, perkawinan tersebut tidak dapat dicatatkan maka petitum tersebut harus ditolak."

Masih menurut penulis, majelis kasasi tidak perlu menyinggung masalah pengadilan agama tidak berwenang mengadili perkara isbat nikah yang dilakukan setelah berlakunya UndangUndang Perkawinan pada tahun 1974. Karena hal itu akan mempersempit kewenangan pengadilan agama dan sangat kontraproduktif dengan program justice for all yang digelontorkan Mahkamah Agung. Salah satunya melalui isbat nikah massal yang dilakukan di luar negeri, sebagaimana tertuang dalam Surat Keputusan Ketua Mahkamah Agung Nomor 084/KMA/ SK/V/2011 tentang Izin Sidang Pengesahan Perkawinan(IsbatNikah), tertanggal $25 \mathrm{Mei}$ 2011 yang menunjuk Pengadilan Agama Jakarta Pusat sebagai pelaksananya, yang sudah dilaksanakan di negara Malaysia.

Logikanya, mana mungkin ada warga negara Indonesia yang menjadi tenaga kerja Indonesia menikah sebelum berlakunya Undang-Undang Perkawinan? Sudah dapat dipastikan warga negara Indonesia tersebut menikah setelah berlakunya Undang-Undang Perkawinan. Di dalam negeri, Mahkamah Agung juga meluncurkan program sidang keliling isbat nikah terpadu, sebagaimana diatur dalam Surat Edaran Mahkamah Agung Nomor 3 Tahun 2014 tentang Tata Cara Pelayanan dan Pemeriksaan Perkara Voluntair Isbat Nikah dalam Pelayanan Terpadu, yang telah dicabut dan diganti dengan Peraturan Mahkamah Agung Nomor 1 Tahun 2015 tentang Pelayanan Terpadu Sidang Keliling Pengadilan Negeri dan Pengadilan Agama dalam Rangka Penerbitan Akta Perkawinan, Buku Nikah, dan Akta Kelahiran.

Menurut penulis, kalau pertimbangannya seperti tertera pada angka 1,2, dan 3 putusan kasasi tersebut, maka petitum angka 2 tersebut lebih baik dinyatakan tidak dapat diterima (bukan ditolak), dengan pertimbangan/alasan hukum sebagai berikut:

a. Bahwa berdasarkan penjelasan Pasal 49 ayat (2) Undang-Undang Nomor 3 Tahun 2006 tentang Perubahan Atas Undang-Undang Nomor 7 Tahun 1989 tentang Peradilan Agama dan perubahan kedua dengan UndangUndang Nomor 50 Tahun 2009 pada poin 22 Pengadilan Agama hanya diberikan kewenangan untuk mengisbatkan perkawinan yang terjadi sebelum berlakunya UndangUndang Perkawinan tahun 1974 (Anshary MK, 2010: 34-35).

b. Bahwa masalah isbat nikah AM sudah pernah diajukan ke Pengadilan Agama Tigaraksa. Tanggal 18 Juni 2008 Pengadilan Agama Tigaraksa membacakan penetapan permohonan 
tersebut, yang pada intinya menolak permohonan pemohon (AM). Dalam hukum acara perdata dikenal istilah fakta-fakta yang sudah diketahui oleh masyarakat umum dan tidak perlu dibuktikan lagi (notoir feiten) (Harahap, 2013: 510). Menurut penulis putusan pengadilan merupakan produk lembaga publik, dan ketika pembacaan putusan juga dinyatakan terbuka untuk umum, berarti putusan pengadilan termasuk suatu fakta yang sudah diketahui oleh masyarakat umum. Dalam perkara ini, bahkan penggugat (AM) mengajukan penetapan Pengadilan Agama Tigaraksa tersebut sebagai salah satu bukti surat yang diberi tanda P.7. Dengan demikian majelis hakim sudah mengetahui perkawinan tersebut dilangsungkan setelah berlakunya Undang-Undang Perkawinan, sehingga petitum angka 2 masalah isbat nikah harus dinyatakan tidak dapat diterima. Karena berdasarkan Pasal 132 Rv yang menyatakan "dalam hal hakim tidak berwenang karena jenis pokok perkaranya, maka ia meskipun tidak diajukan tangkisan tentang ketidakwenangannya, karena jabatannya wajib menyatakan dirinya tidak berwenang." Poin yang dimaksud dalam pasal ini adalah hakim secara ex-officio, wajib menyatakan diri tidak berwenang mengadili perkara yang diperiksanya, apabila perkara diajukan secara absolut berada di luar yurisdiksinya, atau termasuk dalam kewenangan lingkungan peradilan lain. Kewajiban tersebut mesti dilakukan secara ex-officio meskipun tergugat tidak mengajukan eksepsi tentang itu (Mertokusumo, 2006: 86).

2) Untuk menganalisis pertimbangan hukum pada angka 4, 5, dan 6, yang pada pokoknya menyatakan bahwa antara petitum angka 3 dengan petitum angka 4 kontradiktif, bahwa anak yang sah lahir dari perkawinan yang sah, karena petitum angka 2 tentang isbat nikah sudah ditolak, maka petitum angka 3 juga harus ditolak.

Menurut penulis pertimbangan hukum angka 4 sepertinya premis mayor, dan pertimbangan hukum angka 5 sepertinya premis minor, dan pertimbangan hukum angka 6 sepertinya konklusi. Namun antara pertimbangan hukum angka 4 dan pertimbangan hukum angka 5 tidak ada relevansinya, karena pada pertimbangan hukum angka 4 majelis hakim menyoroti dari segi hukum formal (hukum acara perdata). Sedangkan pada pertimbangan hukum angka 5 majelis hakim menyoroti dari segi hukum materiil, dan konklusinya diambil dari pertimbangan hukum angka 5, yaitu ditolak.

Apabila majelis hakim menekankan pada hukum formal dengan alasan terdapat kontradiktif antara petitum angka 3 dengan petitum angka 4, maka gugatan tersebut menjadi kabur (obscuur libel). Sehingga petitum tersebut harus dinyatakan tidak dapat diterima. Sebagaimana diterapkan dalam Putusan Nomor 582 K/Sip/1973, tanggal 18 Desember 1975, di mana kaidah hukumnya menyatakan "karena petitum gugatan adalah tidak jelas, gugatan harus dinyatakan tidak dapat diterima." Namun dalam perkara ini konklusinya ditolak, yang berarti majelis hakim menekankan pada hukum materiilnya.

Apabila majelis hakim menekankan pada hukum materiilnya, maka pertimbangan tersebut sudah sesuai dengan ketentuan Pasal 42 Undang-Undang Perkawinan jo. Pasal 99 Kompilasi Hukum Islam. Karena sebagaimana sudah 
dikatakan di atas, anak yang sah adalah anak yang lahir dari perkawinan yang sah sebagaimana ketentuan Pasal 2 UndangUndang Perkawinan. Karena petitum angka 2 tentang isbat nikah sudah ditolak, berarti perkawinan antara AM dengan $M$ hanya sah secara agama dan tidak sah menurut hukum negara. Maka kedudukan anak tersebut tidak dapat dinyatakan sebagai anak sah AM dan $M$, melainkan hanya sebagai anak AM saja dan hanya mempunyai hubungan perdata dengan AM dan keluarga AM, sehingga sudah tepat petitum angka 3 tersebut ditolak.

Meskipun hasil akhirnya sudah tepat yaitu ditolak, namun sebenarnya majelis kasasi cukup dengan mengambil alih pertimbangan hukum judex facti (Pengadilan Agama Jakarta Selatan dan Pengadilan Tinggi Agama Jakarta) karena pertimbangan hukum majelis kasasi hanya mengulang-ulang pertimbangan hukum judex facti tersebut. Meskipun ditambahkan sedikit pertimbangan, namun pertimbangan tambahan tersebut tidak mempunyai konklusi sehingga penambahan pertimbangan tersebut menjadi mubazir.

3) Untuk menganalisis pertimbangan hukum pada angka 7, yang pada pokoknya menyatakan bahwa pengadilan agama tidak berwenang mengadili perkara anak di luar kawin karena tidak terdapat dalam ketentuan Pasal 49 Undang-Undang Nomor 3 Tahun 2006 tentang Perubahan Atas Undang-Undang Nomor 7 Tahun 1989 tentang Peradilan Agama, dan perubahan kedua dengan Undang-Undang Nomor 50 Tahun 2009, dan judex facti (Pengadilan Tinggi Agama Jakarta dan Pengadilan
Agama Jakarta Selatan) yang mengabulkan tuntutan penggugat tentang status anak di luar kawin adalah putusan yang telah menyimpang dari tugas dan wewenang hakim pada peradilan agama yang wajib memutus berdasarkan hukum Islam, sebagaimana hasil kesepakatan ulama dan cendekiawan Muslim Indonesia yang telah dituangkan di dalam hukum perkawinan Kompilasi Hukum Islam, maka petitum angka 4 harus ditolak.

Penulis akan menganalisis pertimbangan hukum tersebut dari segi hukum acara perdata (hukum formal), lebih spesifik lagi dengan menggunakan teori kewenangan. Untuk menjawab pertanyaan, apakah kewenangan pengadilan agama di bidang perkawinan hanya terbatas pada 22 poin saja, sebagaimana telah disebutkan dalam pertimbangan hukum Putusan Nomor 329 K/AG/2014.

\section{Kewenangan Pengadilan Agama di Luar Undang-Undang Peradilan Agama}

Pada pertimbangan hukum Pengadilan Agama Jakarta Selatan tidak disebutkan dasar hukum pengadilan agama berwenang mengadili gugatan anak di luar kawin. Majelis hakim hanya menyandarkan kewenangan tersebut pada Pasal 56 ayat (1) Undang-Undang Nomor 39 Tahun 1999 tentang Hak Asasi Manusia dan Pasal 7 Undang-Undang Nomor 23 Tahun 2002 tentang Perlindungan Anak, yang intisarinya bahwa hak anak untuk mengetahui orang tuanya (ayah dan ibunya) adalah hak dasar anak yang harus dipenuhi, dalam hal ini melalui pengadilan.

Pembiaran terhadap anak yang ingin mendapatkan kepastian tentang siapa orang tuanya 
adalah suatu pelanggaran terhadap hak asasi anak. Majelis hakim Pengadilan Agama Jakarta Selatan tidak mendasarkan kewenangannya pada Putusan Nomor 46/PUU-VIII/2010 dengan alasan dalam putusan tersebut tidak terdapat klausul yang dapat dimaknai berlaku surut (retroaktif), sehingga Putusan Mahkamah Konstitusi tersebut tidak berlaku bagi perkara ini.

Menurut penulis, pertimbangan kewenangan tersebut menjadi tidak berdasar karena pasal-pasal yang disetir oleh majelis hakim bukan berbicara masalah kewenangan peradilan, namun berbicara masalah hak anak. Sehingga menjadi kurang tepat apabila dengan alasan tidak terdapat klausul yang dapat dimaknai berlaku surut (retroaktif), menyebabkan Putusan Mahkamah Konstitusi tersebut tidak berlaku bagi perkara ini. Masalah eksistensi Putusan Mahkamah Konstitusi akan dibahas pada bagian tersendiri.

Menurut penulis, terdapat beberapa kewenangan yang diberikan oleh peraturan perundang-undangan lain di luar Pasal 49 Undang-Undang Peradilan Agama tersebut, dan kewenangan tersebut diakui eksistensinya oleh Mahkamah Agung in casu kamar agama, antara lain:

1) Permohonan wali adhal, yaitu permohonan agar wali nasab yang mempunyai kekuasaan untuk menikahkan mempelai wanita yang berada di bawah perwaliannya, tetapi ia enggan atau tidak mau menikahkan sebagaimana layaknya seorang wali yang baik. Sehingga oleh pengadilan agama wali nasab tersebut dinyatakan adhal. Kewenangan tersebut diberikan oleh Pasal 23 ayat (1) dan (2) Kompilasi Hukum Islam jo. Pasal 2 ayat (3) Peraturan Menteri
Agama Nomor 2 Tahun 1987 tentang Wali Hakim, yang telah diganti dengan Pasal 2 ayat (1) dan (2) Peraturan Menteri Agama Nomor 30 Tahun 2005 tentang Wali Hakim jo. Pasal 19 ayat (8) Peraturan Menteri Agama Nomor 477 Tahun 2004 tentang Pencatatan Nikah, yang telah diganti dengan Pasal 18 ayat (5) Peraturan Menteri Agama Nomor 11 Tahun 2007 tentang Pencatatan Nikah. Kewenangan tersebut diakui oleh Mahkamah Agung sebagaimana dicontohkan dalam Putusan Nomor $301 \mathrm{~K} /$ AG/2012.

2) Permohonan perubahan biodata pada akta nikah, yaitu permohonan perubahan identitas/biodata suami, istri atau wali. Baik karena salah tulis/ketik, atau tidak sesuai dengan identitas yang sudah ada sebelumnya, seperti KTP, SIM, KK, ijazah, dan SK bagi PNS/pegawai BUMN. Kewenangan tersebut diberikan Pasal 34 ayat (2) Peraturan Menteri Agama Nomor 11 Tahun 2007 tentang Pencatatan Nikah. Kewenangan tersebut diakui oleh Mahkamah Agung seperti dicontohkan dalam Putusan Nomor 290 K/AG/2011.

3) Gugatan mahar, yaitu gugatan diajukan oleh istri atau mantan istri karena suami atau mantan suami belum melunasi mahar terhutang yang dijanjikan pada saat akad nikah, atau apabila terjadi selisih pendapat mengenai jenis dan nilai mahar yang ditetapkan. Kewenangan ini diberikan oleh Pasal 30, 33, dan 37 Kompilasi Hukum Islam. Dalam praktik biasanya gugatan mahar diakumulasikan dengan gugatan cerai, sehingga ia menjadi assesoir dalam perkara cerai gugat, atau diajukan dalam gugatan rekonvensi dalam perkara 
cerai talak. Kewenangan ini diakui oleh Mahkamah Agung seperti dicontohkan dalam Putusan Nomor 23 K/AG/2012. Bahkan tidak tertutup kemungkinan gugatan mahar diajukan secara tersendiri sebelum atau sesudah perceraian terjadi. Kewenangan ini diakui oleh Mahkamah Agung seperti dicontohkan dalam Putusan Nomor 19 K/AG/2007 jo. Putusan Nomor $71 \mathrm{PK} / \mathrm{AG} / 2008$.

4) Gugatan nusyuz, yaitu gugatan yang diajukan oleh suami karena istri dianggap telah telah melakukan perbuatan nusyuz (tidak setia) kepadanya. Kewenangan ini diberikan oleh Pasal 84 ayat (4) jo. Pasal 80 Kompilasi Hukum Islam. Kewenangan ini diakui oleh Mahkamah Agung seperti dicontohkan dalam Putusan Nomor 793 K/ $\mathrm{AG} / 2016$.

5) Permohonan sita harta besama tanpa perceraian, yaitu permohonan sita terhadap harta besama tanpa adanya perceraian dalam hal salah satu dari suami istri melakukan perbuatan yang merugikan dan membahayakan harta bersama, seperti judi, mabuk, boros, dan sebagainya. Kewenangan ini diberikan oleh Pasal 95 ayat (1) Kompilasi Hukum Islam. Kewenangan ini sudah dipraktikkan oleh Pengadilan Agama Jakarta Pusat seperti dicontohkan dalam Putusan Nomor 549/ PDT.G/2007/PA.JP.

6) Permohonan agar seseorang dinyatakan dalam keadaan mafqud (hilang), yaitu permohonan yang diakukan oleh ahli waris agar seseorang yang tidak diketahui kabar beritanya, tidak diketahui tempat tinggalnya, dan tidak diketahui pula hidup, atau matinya dapat dinyatakan mati secara hukum dengan segala akibat hukumnya, dengan persyaratan tertentu. Dalam praktik di pengadilan agama biasanya permohonan tersebut dikumulasikan dengan penetapan ahli waris, namun tidak tertutup kemungkinan diajukan secara tersendiri sesuai kebutuhan yang berkepentingan. Kewenangan ini diberikan oleh Pasal 96 ayat (2) dan Pasal 171 Kompilasi Hukum Islam.

7) Permohonan suami tidak mau membacakan dan menandatangani sighat taklik, yaitu permohonan yang diajukan oleh istri karena suami tidak mau membacakan dan menandatangani sighat taklik pada kutipan akta nikah. Kewenangan ini diberikan oleh Pasal 24 Peraturan Menteri Agama Nomor 11 Tahun 2007 tentang Pencatatan Nikah.

Berdasarkan pemaparan tersebut, Mahkamah Agung in casu kamar agama mengakui adanya kewenangan pengadilan agama yang diberikan oleh peraturan perundang-undangan lain di luar Pasal 49 Undang-Undang Peradilan Agama tersebut. Tetapi, mengapa majelis hakim dalam Putusan Nomor 329 K/AG/2014 tidak mengakui adanya kewenangan lain sebagai imbas dari Putusan Mahkamah Konstitusi? Apakah Putusan Mahkamah Konstitusi lebih rendah dari Peraturan Menteri Agama atau Instruksi Presiden (Kompilasi Hukum Islam)?

\section{Eksistensi Putusan Mahkamah Konstitusi}

Mahkamah Konstitusi mempunyai beberapa kewenangan, di antaranya yang paling banyak mendapat perhatian adalah kewenangan mengadili pada tingkat pertama dan terakhir yang 
putusannya bersifat final untuk menguji undangundang terhadap UUD NRI 1945. Hal ini dikenal dengan istilah judicial review. Putusan Nomor 46/PUU-VIII/2010 merupakan hasil dari judicial review.

Pasal 10 ayat (1) Undang-Undang Nomor 8 Tahun 2011 tentang Perubahan Atas UndangUndang Nomor 24 Tahun 2003 tentang Mahkamah Konstitusi (Undang-Undang Mahkamah Konstitusi) menegaskan bahwa Putusan Mahkamah Konstitusi bersifat final. Putusan Mahkamah Konstitusi langsung memperoleh kekuatan hukum tetap sejak diucapkan dan tidak ada upaya hukum yang dapat ditempuh.

Sifat final dalam Putusan Mahkamah Konstitusi mencakup pula kekuatan hukum mengikat (final and binding). Karena Putusan Mahkamah Konstitusi mengikat umum, pihakpihak yang terkait dengan pelaksanaan ketentuan undang-undang yang telah diputus Mahkamah Konstitusi harus melaksanakan putusan itu. Namun demikian, mengingat norma dalam undang-undang adalah satu kesatuan sistem, ada pelaksanaan putusan yang harus melalui tahapantahapan tertentu, bergantung pada substansi putusan. Ada putusan yang dapat dilaksanakan langsung tanpa harus dibuat peraturan baru atau perubahan, ada pula yang memerlukan pengaturan lebih lanjut terlebih dahulu.

Putusan yang langsung dapat dilaksanakan adalah putusan membatalkan norma tertentu yang tidak mengganggu sistem norma yang ada dan tidak memerlukan pengaturan lebih lanjut. Misalnya, putusan yang mengembalikan hak pilih mantan anggota PKI dengan membatalkan ketentuan Pasal 60 huruf g Undang-Undang Nomor 12 Tahun 2003 tentang Pemilihan Umum. Sejak putusan itu diucapkan, yaitu tanggal 24
Februari 2004, hak pilih mantan anggota PKI telah dipulihkan.

Putusan lain yang langsung dapat dilaksanakan adalah Putusan Mahkamah Konstitusi yang membatalkan pasal-pasal tentang penghinaan presiden dalam KUHP, yaitu Pasal 134, 136 bis, dan 137. Sejak putusan ini diucapkan dalam sidang Mahkamah Konstitusi, tidak seorang pun dapat dipidana berdasarkan pasal-pasal itu. Kepolisian tidak dapat menjadikan pasal-pasal itu sebagai dasar penyelidikan dan penyidikan. Demikian pula penuntutan oleh kejaksaan. Putusan Mahkamah Konstitusi berlaku serta merta, meskipun belum ada perubahan terhadap KUHP.

Terdapat pula putusan yang untuk pelaksanaannya membutuhkan aturan lebih lanjut, yaitu putusan membatalkan suatu norma yang memengaruhi norma-norma lain, atau untuk melaksanakannya diperlukan aturan yang lebih operasional. Putusan Mahkamah Konstitusi mengenai calon perseorangan dalam pemilukada dan putusan mengenai suara terbanyak adalah contoh jenis putusan ini. Namun demikian, belum adanya peraturan yang menindaklanjuti Putusan Mahkamah Konstitusi tidak mengurangi kekuatan mengikat yang telah melekat sejak dibacakan. Setiap pihak yang terkait harus melaksanakan putusan itu. Apabila ada peraturan yang dilaksanakan ternyata bertentangan dengan Putusan Mahkamah Konstitusi, maka yang menjadi dasar hukum adalah Putusan Mahkamah Konstitusi.

Terdapat beberapa Putusan Mahkamah Konstitusi yang diakui eksistensinya oleh Mahkamah Agung in casu kamar agama, di antaranya kewenangan mutlak perkara ekonomi syariah, yakni gugatan perdata yang timbul 
akibat transaksi yang berprinsip syariah, baik berupa pembatalan akad, ingkar/cedera janji (wanprestasi) maupun perbuatan melawan hukum (onrechtmatige daad). Putusan Nomor 93/ PUU-X/2012, di mana pada pokoknya Mahkamah Konstitusi menyatakan bahwa Penjelasan Pasal 55 ayat (2) Undang-Undang Nomor 21 Tahun 2008 tentang Perbankan Syariah bertentangan dengan UUD NRI 1945, sehingga tidak mempunyai kekuatan hukum mengikat. Norma Putusan Mahkamah Konstitusi tersebut sudah diterapkan dalam Pengadilan Negeri Cilacap Nomor 64/PDT.G/2013/PN.CLP.

Berdasarkan Pasal 59 ayat (2) UndangUndang Mahkamah Konstitusi menegaskan “jika diperlukan perubahan terhadap undang-undang yang telah diuji, DPR atau presiden segera menindaklanjuti Putusan Mahkamah Konstitusi sesuai dengan peraturan perundang-undangan." Maksudnya, apabila hasil dari judicial review belum ditindaklanjuti oleh DPR atau presiden, maka hasil dari judicial review menjadi dasar untuk diterapkan dalam perkara yang berkaitan dengan norma tersebut. Selama ini pengadilan agama juga berwenang mengadili perkara permohonan/gugatan anak di luar kawin, dalam bentuk pengingkaran anak maupun pengakuan anak seperti dicontohkan dalam Putusan Nomor $163 \mathrm{~K} / \mathrm{AG} / 2011$. Maka menurut penulis dengan penafsiran argumentum a contrario (mafhum mukhalafah), berarti pengadilan agama juga berwenang mengadili gugatan pengakuan anak di luar kawin.

Pasal 49 huruf (a) Undang-Undang Nomor 3 Tahun 2006 tentang Perubahan Atas UndangUndang Nomor 7 Tahun 1989 tentang Peradilan Agama dan perubahan kedua dengan UndangUndang Nomor 50 Tahun 2009, dalam penjelasan huruf (a) tersebut dinyatakan bahwa "Yang dimaksud dengan "perkawinan" adalah hal-hal yang diatur dalam atau berdasarkan undangundang mengenai perkawinan yang berlaku yang dilakukan menurut syariah, antara lain: terdapat 22 poin."

Penggunaan kata "antara lain" menunjukkan maksud bahwa jenis dan bentuk sengketa dalam bidang perkawinan pada pasal tersebut bersifat enumeratif (penyebutan bersifat terbuka, yang memungkinkan ada jenis lain selain dari yang telah disebutkan). Sehingga kewenangan pengadilan agama untuk mengadili sengketa dalam bidang perkawinan tidak hanya dan tidak terbatas pada jenis dan bentuk perkara yang disebutkan pada penjelasan pasal tersebut, namun juga terbuka bagi jenis dan bentuk sengketa lain sepanjang ruang lingkupnya masih terkait dengan perkawinan yang dilangsungkan antara orang-orang yang tunduk pada hukum Islam.

Menurut penulis meskipun perkara gugatan anak di luar kawin tidak disebutkan secara jelas dalam ketentuan baik dalam Pasal 49 UndangUndang Nomor 3 Tahun 2006 maupun dalam penjelasannya, namun hanya ditegaskan dalam Putusan Nomor 46/PUU-VIII/2010. Maka secara yuridis formal perkara tersebut harus tetap dipandang sebagai kewenangan absolut pengadilan agama, karena terkait erat dengan sengketa rumah tangga yang perkawinannya dilangsungkan menurut hukum Islam, oleh karenanya gugatan anak di luar kawin merupakan kewenangan absolut pengadilan agama.

Berdasarkan argumentasi-argumentasi tersebut, maka Mahkamah Agung in casu kamar agama telah mengakui eksistensi Putusan Mahkamah Konstitusi, dan seharusnya juga mengakui Putusan Nomor 46/PUU-VIII/2010. 
Sehingga menurut penulis, pengadilan agama berwenang mengadili perkara permohonan maupun gugatan anak di luar kawin (anak biologis), yang mana kewenangan tersebut diberikan oleh Putusan Nomor 46/PUUVIII/2010, dan berarti putusan tersebut dapat dijadikan dasar untuk mengadili Putusan Nomor $329 \mathrm{~K} / \mathrm{AG} / 2014$.

Apabila pengadilan agama sudah dinyatakan berwenang mengadili perkara tersebut, maka untuk mengabulkan gugatan tersebut dapat ditempuh dengan dua cara, yakni formalistis dan cara penggabungan antara formalistis dan materiil. Cara formalistis cukup dengan mendasarkan pertimbangan pada Putusan Nomor 46/PUU-VIII/2010. Sedangkan cara penggabungan antara formalistis dan materiil, selain mendasarkan pertimbangan hukum pada Putusan Nomor 46/PUU-VIII/2010 tersebut, juga harus memberikan pertimbangan dari segi teori hukum. Dalam hal ini penulis menggunakan teori keadilan, teori perlindungan hukum, teori hukum progresif, dan teori mashlahah.

\section{1) Teori Keadilan}

Petitum tersebut dapat dikabulkan dengan mempertimbangkan dari segi keadilan. Keadilan dapat diterapkan pada dua sisi. Pertama dari sisi ibu anak tersebut, dan yang kedua dari sisi anak itu sendiri. Wujud keadilan bagi ibunya dapat berupa ayah biologis anak tersebut harus bertanggung jawab dalam memberikan nafkah dan biaya pendidikannya, sehingga dapat meringankan beban ibunya.

Pengakuan ayah biologis terhadap anak tersebut, sehingga oleh masyarakat ia tidak dianggap berbuat zina dengan ayah biologisnya. Diberikan wasiat dari sebagian harta milik ayah biologisnya, sehingga ibunya dapat diringankan dari segi harta.

Keadilan bagi anak tersebut banyak sekali. Namun karena pertimbangan hukum pada Putusan Nomor 329 K/AG/2014 sangat terpaku pada hukum formal (hukum acara perdata), terutama berkaitan dengan kewenangan pengadilan agama yang pada akhirnya hanya menciptakan kepastian hukum saja, tapi tidak menciptakan keadilan. Kepastiannya adalah anak tersebut telah nyata sebagai anak dari orang tua tunggal, yaitu ibunya (AM), dan hanya mempunyai hubungan perdata dengan ibu dan keluarga ibunya saja. Sedangkan ketidakadilannya adalah laki-laki yang menghamilinya (M) tidak bertanggung jawab segalanya dan tanpa dikenakan sanksi apapun.

Ibunya harus bertanggung jawab segalanya, terlebih lagi anaknya akan menanggung derita seumur hidupnya dengan menyandang gelar anak di luar kawin. Padahal idealnya dalam setiap putusan hakim terdapat kepastian, keadilan, dan kemanfaatan hukum. Putusan Nomor 46/ PUU-VIII/2010 telah berusaha menciptakan keadilan antara anak sah dan anak di luar kawin. Karena menciptakan keadilan merupakan suatu kebajikan, sebagaimana pandangan Aristoteles yang mengungkapkan bahwa keadilan adalah kebajikan yang utama.

Berpijak pada prinsip keadilan tersebut, maka akan sangat adil dan bijak bila majelis hakim pada Putusan Nomor 329 K/AG/2014 mengabulkan gugatan tentang petitum angka 4 mengenai anak di luar kawin (anak biologis), yang berarti majelis hakim telah memberikan perlakuan yang sama terhadap anak di luar kawin tersebut di dalam hal memperoleh hak-hak keperdataan dari ayah biologisnya. Meskipun tidak sama persis dengan hak-hak keperdataan 
anak yang sah, artinya hanya pemberian hak keperdataan terbatas.

Misalnya ayah biologis dibebani kewajiban untuk mencukupi kebutuhan hidup anak tersebut sampai dewasa atau berdiri sendiri, dibebani memberikan biaya pendidikan dan dibebani memberikan harta setelah ia meninggal melalui wasiat wajibah maksimal 1/3 dari harta peninggalan, diakui keberadaannya sebagai anak yang lahir dari kasih sayang orang tuanya, sehingga ia tidak dicap sebagai anak dari orang tua tunggal, apalagi dicap sebagai anak hasil zina. Padahal MIR adalah anak AM dan M yang lahir akibat perkawinan siri, yang mana perkawinan siri merupakan perkawinan yang sah secara agama dan diakui keberadaannya oleh mayoritas masyarakat Indonesia, hanya tidak tercatat secara administrasi negara.

\section{2) Teori Perlindungan Hukum}

Petitum tersebut dapat dikabulkan dengan mempertimbangkan dari segi perlindungan hukum, lebih spesifik lagi, perlindungan hukum bagi anak. Ada dua hal penting yang harus diperhatikan dalam perlindungan anak, yaitu: pertama, segala daya upaya yang dilakukan secara sadar oleh setiap orang ataupun lembaga pemerintah dan swasta bertujuan mengusahakan pengamanan dan pemenuhan kesejahteraan fisik, mental dan sosial anak dan remaja yang sesuai dengan kepentingan dan asasinya. Kedua, segala daya dan upaya bersama yang dilakukan dengan sadar oleh perseorangan, keluarga dan masyarakat, badan-badan pemerintah dan swasta untuk pengamanan, pengadaan dan pemenuhan kesejahteraan rohani dan jasmani anak yang tidak atau belum pernah menikah sesuai dengan hak dan kepentingan agar dapat mengembangkan hidupnya seoptimal mungkin (Sujana, 2015: 221-222).

Wujud konkret perlindungan anak adalah terjamin dan terlindunginya hak-hak anak agar dapat hidup, tumbuh, berkembang, dan berpartisipasi secara optimal sesuai dengan harkat dan martabat kemanusiaan, serta mendapat perlindungan dari kekerasan dan diskriminasi. Sehingga ia mendapat tempat yang hampir sama dengan kedudukan anak sah dalam memperoleh hak, seperti memperoleh nafkah dan biaya pendidikan dari ayah biologisnya, dan memperoleh kedudukan, penghormatan dan status sosial yang sama dengan anak sah di lingkungan sekitarnya.

Tidak dikabulkannya petitum tersebut, anak tersebut tidak mendapat perlindungan hukum baik secara resmi administrasi negara maupun secara status sosial di masyarakat lingkungan sekitarnya. Anak tersebut akan terus menyandang anak dari orang tua tunggal, padahal ia lahir dari kasih sayang orang tuanya, hanya karena perkawinan mereka tidak tercatat di instansi pemerintah.

\section{3) Teori Hukum Progresif}

Menurut penulis, petitum tersebut dapat dikabulkan dengan mempertimbangkan dari segi hukum progresif. Hukum progresif dapat diterapkan dalam segala aspek, dalam petitum tersebut dapat diterapkan baik pada hukum formal maupun hukum materiilnya. Majelis hakim kasasi terlalu formalistis dan kaku dengan alasan pengadilan agama tidak berwenang, kewenangan (kompetensi) merupakan bagian dari hukum acara perdata. Padahal menurut penulis, hukum acara merupakan jalan untuk menuju kebenaran, menegakkan hukum dan keadilan. Apabila hukum acaranya kaku dengan alasan 
tertib beracara sehingga kebenaran dan keadilan tidak tegak, maka hukum acara tersebut dapat diterobos hanya untuk menegakkan kebenaran dan keadilan tersebut.

Hakim bukan sebagai corong undangundang yang terpaku dengan ketidaksempurnaan. Tugas hakimlah yang harus menyempurnakan hukum acara yang kaku tersebut. Sehingga terlihat majelis hakim kasasi terlalu formalistik dan cenderung kaku dalam menyikapi kewenangan (kompetensi) absolut pengadilan agama. Dari hukum materiil pun majelis hakim kasasi terlalu berpegang pada Pasal 100 Kompilasi Hukum Islam. Padahal pasal tersebut lahir dari Pasal 43 Undang-Undang Perkawinan, sebagaimana disebutkan dalam pertimbangannya "putusan judex facti yang telah menyimpang dari tugas dan wewenang hakim pada peradilan agama yang wajib memutus berdasarkan hukum Islam, sebagaimana hasil kesepakatan ulama dan cendekiawan Muslim Indonesia yang telah dituangkan di dalam hukum perkawinan Kompilasi Hukum Islam." Sedangkan Pasal 43 tersebut sudah dinyatakan tidak berkekuatan hukum berdasarkan Putusan Nomor 46/PUUVIII/2010. Dengan demikian secara otomatis norma yang terdapat pada Pasal 100 Kompilasi Hukum Islam juga tidak berkekuatan hukum. Berarti yang harus dipakai adalah norma yang telah digariskan oleh Putusan Mahkamah Konstitusi tersebut.

Menurut penulis juga dapat dimasukkan nilai-nilai hukum progresif dalam pertimbangan hukum pada petitum tersebut, yaitu: (a) menempatkan "hukum untuk manusia" bukan "manusia untuk hukum.. Karena apabila petitum tersebut dikabulkan, berarti Mahkamah Agung berusaha mendudukkan anak di luar kawin hampir setaraf dengan anak sah dalam memperoleh hak keperdataan dari ayah biologisnya, meskipun hanya hak-hak yang terbatas; (b) merespon keinginan pencari keadilan untuk memberikan perlindungan hak-hak keperdataan bagi anak di luar kawin, yaitu pengakuan dari bapak biologisnya; (c) memberikan nilai kesejahteraan dan kebahagiaan, tidak saja bagi ibu yang melahirkan, juga keluarga ibunya, utamanya bagi anak yang dilahirkan di luar perkawinan yang sah; (d) mengakomodir keinginan publik dengan melakukan rule breaking (terobosan hukum) oleh hakim dalam mengaktualisasikan hukum dalam ruang dan waktu yang tepat dan melakukan pemaknaan yang kreatif terhadap peraturan yang ada, tanpa harus menunggu perubahan peraturan (changing of law). Tujuannya adalah agar hukum juga mengatur dan menjamin hakhak keperdatan anak di luar kawin yang selama ini belum mendapatkan perlindungan hukum; (e) mengejawantahkan sebuah putusan yang memiliki kecerdasan moral dan spiritual dengan kandungan nilai keadilan substantif yang lebih dalam; (f) mengganti dan menerobos paradigma bekerjanya hukum sesuai peraturan menuju ke paradigma perilaku manusia, yaitu melihat tujuan sosial yang ingin dicapai dari bekerjanya hukum.

Tulisan Zakyyah dengan judul "Nasab Anak Luar Kawin Menurut Hifzhu Nasl (Kajian Putusan Mahkamah Konstitusi Nomor 46/PUUVIII/2010)" mendukung pernyataan penulis. Intisari isi tulisannya adalah:

"Putusan Nomor 46/PUU-VIII/2010 bertentangan dengan teori hifzhu nasl, namun jika hubungan perdata yang dimaksud hanya kewajiban timbal balik terbatas pada hal pemberian nafkah, maka putusan ini sangat tepat dan sesuai dengan teori hifzhu nafs dalam maq asid alsyar'iyyah, karena menjaga jiwa anak (hifzu $n a f s$ ) dari keterpurukan dan kesengsaraan merupakan kemaslahatan aldaruriyyah yang harus dijaga" (Zayyah, 2016: 212). 
Petitum tersebut dapat dikabulkan dengan mempertimbangkan dari segi teori mashlahah. Di mana teori mashlahah selalu mengedepankan, apakah permasalahan yang dihadapi itu bertentangan dengan syariat atau tidak, dan apakah permasalahan yang dihadapi itu sudah diatur secara jelas atau tidak oleh syariat.

Permasalahan kedudukan anak hasil nikah siri sudah dijelaskan secara panjang lebar oleh AzZuhaili, bahwa anak yang lahir dari perkawinan yang tidak tercatat di instansi pemerintah tetap dapat dinasabkan kepada ayahnya (Az-Zuhaili, 2001: 670). Pendapat ini didasarkan pada praktik nikah siri yang dimaksudkan adalah perkawinan yang dilaksanakan yang telah memenuhi syarat dan rukun nikah menurut hukum Islam, namun tidak dicatatkan pada instansi pemerintah dengan berbagai faktor yang melatarbelakanginya.

Anak yang tidak boleh dinasabkan kepada ayahnya adalah anak yang lahir akibat perbuatan zina, sebagaimana disebutkan dalam beberapa hadis Nabi Muhammad SAW, di antaranya:

Telah menceritakan kepada kami [Yahya bin Qaza'ah] telah menceritakan kepada kami [Malik] dari [Ibnu Syihab] dari ['Urwah bin Az Zubair] dari [Aisyah radhiallahu anha] berkata; Utbah bin Abu Waqash berpesan kepada saudaranya Sa'ad bin Abu Waqash yang isinya "Anak laki-laki dari hamba sahaya Zam'ah adalah anakku maka ambillah." Aisyah radhiallahu anha berkata; Ketika tahun Pembebasan Makkah, Sa'ad bin Abu Waqash mengambilnya, seraya berkata; Itu anak laki-laki saudaraku, yang ia berpesan kepadaku untuk mengambil anak ini. Maka Abd bin Zam'ah berdiri lalu berkata: Oh tidak, karena saudaraku dan anak laki-laki hamba sahaya ayahku dilahirkan di tempat tidurnya. Lalu keduanya mengadukan masalah ini kepada Nabi SAW. Sa'ad berkata: "Wahai Rasulullah, ini adalah anak saudaraku, yang saudaraku telah berpesan kepadaku untuk mengambilnya." Lalu Abd bin Zam'ah berkata: "Saudaraku dan anak laki-laki dari hamba sahaya ayahku dilahirkan pada tempat tidurnya." Lantas Rasulullah SAW berkata: "Dia itu milikmu wahai Abd bin Zam'ah. " Kemudian Nabi SAW bersabda: "Anak itu milik pemilik kasur (suami) sedangkan lelaki pezina baginya adalah batu (dirajam)." Kemudian Beliau berkata kepada Saudah binti Zam'ah istri Nabi SAW: "Berhijablah engkau daripadanya wahai Saudah, yang demikian karena ada kemiripannya dengan 'Utbah'. Maka anak laki-laki dari hamba sahaya Zam'ah itu tidak pernah melihat Saudah selama-lamanya hingga Saudah berjumpa dengan Allah." (HR. Bukhari) (Al-Bukhari, 2010: 75).

Dari Sahal bin Sa'ad, ia berkata: Aku telah menghadiri sumpah li'an keduanya, yang disaksikan oleh Nabi. Aku saat itu berumur lima belas tahun, kemudian menuturkan hadits seperti tadi... Dalam hadits tersebut ia mengatakan: "Sang wanita lalu keluar dalam keadaan hamil, maka anaknya nanti dinisbatkan kepada ibunya." (HR. Abu Dawud) (Dawud, 2011: 391).

Di Indonesia, masalah anak zina sudah dijelaskan dalam Fatwa Majelis Ulama Indonesia Nomor 11 Tahun 2012 tentang Kedudukan Anak Hasil Zina dan Perlakuan Terhadapnya, yang menyatakan: (1) Anak hasil zina tidak mempunyai hubungan nasab, wali nikah, waris, dan nafaqah dengan lelaki yang menyebabkan kelahirannya; (2) Anak hasil zina hanya mempunyai hubungan nasab, waris, dan nafaqah dengan ibunya dan keluarga ibunya; dan (3) Anak hasil zina tidak menanggung dosa perzinaan yang dilakukan oleh orang yang mengakibatkan kelahirannya. Kembali pada permasalahan pokok masalah petitum angka 4 dapat dikabulkan, apabila Mahkamah Agung tidak terlalu formalistis dan kaku dengan menerapkan teori mashlahah, dengan mempertimbangan perkawinan AM dan $\mathrm{M}$ karena telah terbukti AM dan M adalah 
perkawinan yang sah secara agama, namun tidak tercatat di instansi pemerintah.

Artinya perkawinan mereka diakui keabsahannya oleh syariat. Ini merupakan pintu masuk untuk menerapkan teori mashlalah, karena perkawinan mereka sah secara agama namun kedudukan perkawinan tersebut tidak dilindungi oleh negara. Sehingga akibat dari itu, kedudukan anak tersebut menjadi tidak terlindungi. Maka untuk memadukan antara hukum Islam yang berkembang di masyarakat dengan hukum negara, dan untuk melindungi anak tersebut negara dapat mendudukan anak tersebut sebagai anak di luar kawin, yang mempunyai hubungan keperdataan secara mutlak dengan ibu dan keluarganya, dan mempunyai hubungan keperdataan secara terbatas dengan ayah biologis dan keluarganya.

Kemaslahatan yang ditimbulkan apabila petitum tersebut dikabulkan, misalnya dari sisi ibunya: hilangnya stigma sebagai pelaku zina dan meringankan beban dari segi ekonomi; dari sisi anak tersebut: hilangnya stigma sebagai anak hasil zina, diakui kedudukannya secara normal di lingkungan masyarakatnya, mendapat nafkah dan biaya pendidikan dari ayah biologisnya, dan mendapat harta warisan melalui hibah atas wasiat wajibah dari ayah biologisnya.

Kemudaratan yang ditimbulkan apabila petitum tersebut ditolak, misalnya dari sisi ibunya: melekatnya stigma sebagai pelaku zina dan menanggung beban sendiri dari segi ekonomi; dari sisi anak tersebut: melekatnya stigma sebagai anak hasil zina, tidak diakui kedudukannya secara normal di lingkungan masyarakatnya, tidak mendapat nafkah dan biaya pendidikan dari ayah biologisnya, dan tidak mendapat harta warisan melalui hibah atas wasiat wajibah dari ayah biologisnya.
Mencermati kemaslahatan dan kemudaratan yang timbulkan dari dikabulkan atau ditolaknya petitum tersebut, dengan demikian secara tidak langsung dalam petitum tersebut terdapat dua kemudaratan, yaitu kemudaratan apabila kabulkan dan kemudaratan apabila ditolak. Berdasarkan fakta-fakta hukum apabila dikabulkan, kemungkinan kemudaratan yang akan muncul lebih kecil daripada kemungkinan kemudaratan ditimbulkan apabila ditolak. Maka sesuai kaidah fiqhiyah yang menyatakan: "apabila berkumpul dua kemudaratan, maka kemudaratan yang lebih berat harus dihilangkan dengan kemudaratan yang lebih ringan." Selain itu secara tidak langsung negara telah memberikan sanksi/hukuman berupa takzir terhadap ayah biologisnya dengan membebankan pemberian nafkah, biaya pendidikan, dan warisan untuk anak biologisnya, yang berarti negara telah berhasil memadukan antara hukum Islam yang berkembang di masyarakat dengan hukum yang berlaku.

Kemudian apabila dicermati dan ditafsirkan secara argumentum a contrario terhadap ketentuan angka 1 Fatwa Majelis Ulama Indonesia Nomor 11 Tahun 2012 yang menyatakan: "Anak hasil zina adalah anak yang lahir sebagai akibat dari hubungan badan di luar pernikahan yang sah menurut ketentuan agama," dan faktanya MIR itu bukan anak hasil zina, melainkan anak hasil perkawinan siri yang sah secara agama namun tidak dicatatkan di Kantor Urusan Agama. Artinya, pengadilan agama boleh menetapkan anak hasil kawin siri (bukan anak hasil zina) sebagai anak biologis dari $M$ dan mempunyai hubungan perdata yang terbatas pada $\mathrm{M}$ dan keluarga $\mathrm{M}$. 


\section{KESIMPULAN}

Berdasarkan pembahasan di atas, dapat penulis simpulkan sebagai berikut:

1. Putusan Nomor $329 \mathrm{~K} / \mathrm{AG} / 2014$ sangat mengedepankan aspek yuridis (kepastian hukum), sedangkan aspek sosiologis (kemanfaatan) dan filosofis (keadilan) cenderung diabaikan dan tidak dipertimbangkan sama sekali.

2. Putusan Nomor $329 \mathrm{~K} / \mathrm{AG} / 2014$ tidak menyinggung sama sekali eksistensi Putusan Nomor 46/PUU-VIII/2010 tanggal 17 Februari 2012.

3. Berdasarkan teori keadilan, teori perlindungan, teori kewenangan, teori hukum progresif, dan teori mashlahah, petitum tentang anak di luar kawin dapat dikabulkan tidak hanya untuk menciptakan kepastian hukum, juga untuk menciptakan keadilan dan kemanfaatan hukum.

Kepastiannya adalah anak tersebut telah nyata bahwa anak tersebut hanya mempunyai hubungan perdata dengan ibunya. Sedangkan ketidakadilannya adalah laki-laki yang menghamilinya tidak bertanggung jawab segalanya dan tanpa dikenakan sanksi apapun, dan ibunya harus bertanggung jawab segalanya. Terlebih lagi anaknya akan menanggung derita seumur hidupnya dengan menyandang gelar anak di luar nikah. Berdasarkan teori perlindungan hukum, anak tersebut tidak mendapat perlindungan dan tidak memperoleh apapun dari ayah biologisnya.

Berdasarkan teori kewenangan, pengadilan agama berwenang memeriksa dan mengadili perkara permohonan/gugatan anak biologis meskipun tidak disebutkan dalam paket Undang-Undang Peradilan Agama, di mana kewenangan tersebut diberikan atau akibat Putusan Nomor 46/ PUU-VIII/2010, yang bersifat final dan mempunyai kekuatan hukum mengikat (final and binding).

Berdasarkan teori hukum progresif, Putusan Nomor 329 K/AG/2014 tersebut cenderung formalistis dan kaku, akibatnya tidak mencerminkan keadilan sehingga perlu dipadukan dengan hukum yang responsif atau progresif. Menurut teori mashlahah, apabila ditimbang antara manfaat dan mudarat yang timbulkan apabila gugatan anak biologis pada Putusan Nomor 329 K/ AG/2014 tersebut dikabulkan atau ditolak, maka akan lebih mashlahah apabila dikabulkan dengan menetapkan anak tersebut sebagai anak biologis dari laki-laki yang menghamili ibunya. Dengan alasan perkawinan ibu dan ayah biologisnya tersebut sah secara agama. Akibatnya ayah biologisnya mendapat sanksi berupa harus bertanggung jawab pada batasbatas tertentu terhadap anak tersebut, dan anak tersebut akan mendapat keadilan, kepastian, dan perlindungan hukum.

\section{DAFTAR ACUAN}

Al-Bukhari, I. (2010). Al-Jami' As-Shahih atau Shahih Bukhari. Kairo: As-Salafiyah.

Anshary MK, M. (2010). Hukum perkawinan di Indonesia: Masalah-masalah krusial. Yogyakarta: Pustaka Pelajar. 
Az-Zuhaili, W. (2001). Al-Fiqh Al-Islam wa Adilatuh. Bairut: Dar al-Fikr.

Dawud, A. (2011). Sunan Abu Daud. Riyad: Maktabah Sa'ad bin Abdurrahman.

Hadjon, P.M. (2007). Perlindungan hukum bagi rakyat Indonesia. Surabaya: M2 Print.

Harahap, M.Y. (2013). Hukum acara perdata tentang gugatan, persidangan, penyitaan, pembuktian, \& putusan pengadilan. Jakarta: Sinar Grafika.

Manan, A. (2007). Reformasi hukum Islam di Indonesia: Tinjauan dari aspek metodologis, legalisasi, \& yurisprudensi. Jakarta: Raja Grafindo Persada.

. (2014). Aneka masalah hukum perdata Islam di Indonesia. Jakarta: Kencana Prenada Media Group.

Mertokusumo, S. (2006). Hukum acara perdata Indonesia. Yogyakarta: LibertyYogyakarta.

Rahardjo, S. (2007). Membedah hukum progresif. Jakarta: Kompas Media Nusantara.

Rasyidi, L. (1991). Hukum perkawinan \& perceraian di Malaysia \& Indonesia. Bandung: Remaja Rosdakarya.

Rofiq, A. (2013). Hukum perdata Islam di Indonesia. Jakarta: Raja Grafindo Persada.

Satrio, J. (2005). Hukum keluarga tentang kedudukan anak dalam undang-undang. Bandung: Citra Aditya Bakti.

Sujana, I.N. (2015). Kedudukan hukum anak luar kawin dalam perspektif Putusan Mahkamah Konstitusi Nomor 46/PUU-VIII/2010. Yogyakarta: Aswaja Pressindo.

Sumaryono, E. (1995). Etika profesi hukum: Normanorma bagi penegak hukum. Yogyakarta: Kanisius.
Sutantio, R., \& Oeripkartawinata, I. (2002). Hukum acara perdata dalam teori \& praktik. Bandung: Mandar Maju.

Tobroni, F. (2015, April). Hak anak sebagai ahli waris dalam perkawainan siri. Jurnal Yudisial, 8(1), 85-102.

Zakyyah. (2016, Agustus). Nasab anak luar kawin menurut Hifzhu Nasl (Kajian Putusan Mahkamah Konstitusi Nomor 46/PUUVIII/2010). Jurnal Yudisial, 9(2), 195-214. 